In de rubriek praktijkonderzoek presenteren onderzoekers uit de hbo-lectoraten, docenten of studenten hun onderzoeksresultaten. De resultaten leveren een bijdrage aan innovatie van de zorg- en onderwijspraktijk en dragen bij aan verbetering van de beroeps- en onderwijsontwikkeling van docenten en zorgverleners.

\title{
Levensloopbegeleiding voor mensen met autisme
}

\section{Inleiding}

'Als ik naar autisme kijk, dan is het gewoon zo dat het nooit ophoudt. Je blijft daar je hele leven lang hinder van ondervinden.'

Een autismespectrumstoornis (ASS) is een aangeboren hersenstoornis. De prevalentie wordt op 60 tot 100 per 10.000 mensen geschat (Gezondheidsraad, 2009). Mensen met ASS hebben veel moeite met informatieverwerking. Communicatie verloopt vaak ingewikkeld, taalkundige nuances, dubbele betekenissen en lichaamstaal worden moeizaam begrepen (Gezondheidsraad, 2009). Hieruit volgen diverse problemen op verschillende levensgebieden: wonen, onderwijs, werk, vrijetijdsbesteding, sociale contacten, vriendschappen en relaties. Het lukt mensen met ASS dan ook vaak niet om een (totaal) zelfstandig leven te leiden en er is regelmatig sprake van een sociaal isolement. Met name transitiemomenten, bijv. de overgang van school naar werk, scheiding of verlies van een dierbare, zijn risicomomenten voor verslechtering van de symptomen. Op deze momenten zou er iemand moeten zijn die de persoon kan bijstaan en van advies kan dienen (Teunisse, 2009). Daarom wordt in het rapport van de Gezondheidsraad uit 2009 'Autismespectrumstoornissen; een leven lang anders' gepleit voor een levensloopbegeleider met als doel om een zo groot mogelijke autonomie van het individu te bereiken. Deze begeleider biedt preventieve en proactieve ondersteuning met name tijdens naderende transitiemomenten. De rol van levensloopbegeleider is echter nog niet ingevuld.

Vandaar dat er een lectoraat Levensloopbegeleiding bij autisme is opgezet, aan de Hogeschool van Arnhem en Nijmegen in samenwerking met het dr. Leo Kannerhuis. Het lectoraat wil de komende jaren onderzoeken op welke wijze invulling kan worden gegeven aan levensloopbegeleiding bij normaal begaafde mensen met ASS.

\section{Doelstelling en vraagstelling}

De doelstelling van onderstaand onderzoek is om door middel van interviews in kaart te brengen wat sleutelfiguren verstaan onder levensloopbegeleiding bij mensen met ASS en het benoemen van overeenkomsten en verschillen. Om deze doelstelling te bewerkstelligen is de volgende vraagstelling geformuleerd:

Wat zijn de visies van sleutelfiguren die betrokken zijn bij de begeleiding en behandeling van een persoon met ASS over levensloopbegeleiding?

Sleutelfiguren zijn mensen die, hetzij door opleiding en/of werkervaring, expertise hebben in de behandeling en/of begeleiding van mensen met ASS en/of het cliëntsysteem; bij voorkeur expertise hebben in meerdere levensfasen en -domeinen en op de hoogte zijn van het rapport van de Gezondheidsraad (2009) over het advies tot invoering van levensloopbegeleiding.

\section{Methode}

Voor het verzamelen van de gegevens is gebruik gemaakt van mondelinge semi-gestructureerde interviews. Om ervoor te zorgen dat bij alle geïnterviewde sleutelfiguren dezelfde onderwerpen aan de orde zouden komen, is gebruikt gemaakt van een topiclist. Deze topiclijst is aan een deskundige voorgelegd. Vervolgens is het instrument verbeterd met behulp van een proefinterview. Voor het selecteren van de sleutelfiguren is gebruik gemaakt van het adressenbestand van het Samenwerkingsverband Autisme Gelderland (SAG). Er is voor dit samenwerkingsverband gekozen, omdat zij een brede afspiegeling vormt van instellingen, instanties en personen die zich bezighouden met de bevordering van zorg voor mensen met ASS. Er zijn twaalf organisaties geselecteerd en aangeschreven om deel te nemen aan het onderzoek. Drie organisaties wilden, om verschillende redenen, niet participeren. Daarnaast is vanuit de vereniging PAS (een belangenvereniging voor en door normaal tot hoger begaafde mensen met ASS) een ervaringsdeskundige in het onderzoek betrokken. Voor de analyse zijn de stappen gevolgd die Baarda (2005) beschrijft, namelijk het opdelen van de tekst in fragmenten, het labelen van deze fragmenten en dit weer tot kernlabels samenvoegen. 


\section{Resultaten}

Levensloopbegeleiding bestaat volgens de respondenten uit zeven kernonderdelen: (1) levenslange toekomstgerichte begeleiding, (2) continuïteit, (3) transitiemomenten, (4) preventieve, proactieve en controlerende zorg, (5) individualistische aanpak, (6) flexibele zorgverlening en (7) samenwerking. Al deze aspecten samen vormen levensloopbegeleiding.

'Wat ik onder levensloopbegeleiding versta, is dat er oog is voor de overgangen in iemands leven en dat er bij allerlei belangrijke overgangen een netwerk rondom de persoon met autisme is, dat de overgangen voorziet en kan helpen.'

Op de vraag wie de levensloopbegeleider zou moeten zijn, antwoordden 5 van de 11 respondenten dat dat de ouders moesten zijn: ouders zijn de meest constante factor in het leven van iemand met ASS. De overige respondenten vonden dat ouders geen primaire rol moeten vervullen betreffende levensloopbegeleiding, met als argumenten: het ontbreekt ouders aan specifieke kennis over ASS en beschikbare zorg, het is voor ouders lastig om objectief naar de persoon met ASS te kijken en er is een discrepantie in verwachtingen. Alle respondenten benoemden het risico van overbelasting van ouders.

'Soms heb je ook te maken met een volslagen uitgeput netwerk dat de rol van levensloopbegeleider niet op zich kan nemen. Dan kan het nodig zijn dat een professional ingeschakeld wordt.'

Een duo-rol; professional \& ouder, wordt door alle respondenten genoemd als een werkbare rolinvulling. De voorstanders van ouders als levensloopbegeleider verwachten handvatten en kennis aangeboden te krijgen van de professional. Professionals hebben specialistische kennis over ASS, bekendheid met subsidieregelingen en het ontwikkelen modules en protocollen.

'Een organisatie weet wat er te halen is en kent goed de weg in hulpverleningsland. Zij kan een gidsfunctie hebben.'

Ook technologische mogelijkheden en ontwikkelingen kunnen een positieve rol spelen in levensloopbegeleiding, maar fysiek contact zal altijd nodig blijven. Op de vraag naar competenties van een levensloopbegeleider wordt kennis door alle respondenten genoemd als belangrijkste. Het huidige beleid omtrent indicatiestelling zorgt er voor dat geen enkele organisatie op dit moment levensloopbegeleiding zou kunnen bieden op de manier waarop dit volgens de respondenten zou moeten. Veel organisaties trachten zorgvragen op te lossen door een zo kort mogelijke begeleiding en dit staat loodrecht tegenover levensloopbegeleiding. Alle respondenten verwachten dat levensloopbegeleiding een positieve input kan hebben in het leven van de persoon met ASS: preventie, continuiteit, toename van de kwaliteit van leven, toename van zelfredzaamheid en ontwikkeling.

\section{Conclusies}

Levensloopbegeleiding is begeleiding gedurende het hele leven, maar gericht op het heden en de toekomst van de persoon met ASS en zijn primaire netwerk en draagt bij aan de ontwikkeling van de persoon met ASS. Het is niet alleen preventief en proactief, maar heeft daarnaast ook een controlerende component en richt zich op het stellen van realistische doelen. Mensen met ASS hebben op bepaalde momenten, voornamelijk rondom transitiemomenten, meer zorg nodig. Dit betekent dan ook dat levensloopbegeleiding individueel ingevuld dient te worden. Levensloopbegeleiding is dan ook flexibel met betrekking tot zorgzwaarte.

De functie van levensloopbegeleider dient tot de adolescentie ingevuld te worden in een duo-rol tussen professional en ouders. Deze combinatie heeft als voordeel dat er een stabiele factor is, namelijk de ouders en er wordt tegelijkertijd gebruikgemaakt van de kennis en kunde van de professional. Vanaf de adolescentie kan de cliënt de rol van ouders overnemen, mits hij hiertoe in staat is. Anders zou het iemand uit zijn omgeving kunnen zijn.

In dit onderzoek komt naar voren dat er een aantal stappen genomen dient te worden voordat levensloopbegeleiding effectief ingevoerd kan worden. De overheid dient een besluit te nemen om levensloopbegeleiding in te voeren; er zullen middelen beschikbaar moeten gesteld voor de implementatie en uitvoering van levensloopbegeleiding; het dient duidelijk te zijn welke organisatie de uitvoering gaat doen en hoe de controle op de uitvoering gestalte krijgt.

\section{Aanbevelingen}

Een aanbeveling is om een Delphi-studie te houden onder een groot aantal experts om consensus te krijgen over wat levensloopbegeleiding eigenlijk inhoudt. Met betrekking tot de duo-rol professional en ouders is het interessant, zeker in het kader van outreaching care, na te gaan over welke competenties de verschillende partijen dienen te beschikken en hoe deze aangeleerd kunnen worden. Hierin zou het lectoraat een rol kunnen spelen. Het $\mathrm{CIZ}$ zou een flexibele invulling van de zorgzwaarte moeten toekennen, gezien het feit dat mensen met ASS meer zorg nodig hebben rondom transitiemomenten.

\section{Referenties}

Baarda, D.B., de Goede, M.P.M., Teunissen, J. (2005). Basisboek kwalitatief onderzoek; handleiding voor het opzetten en uitvoeren van kwalitatief onderzoek. Houten: Stenfert Kroese.

Gezondheidsraad. 2009. Autismespectrumstoornissen; een leven lang anders. Den Haag: Gezondheidsraad, 2009; publicatienr. 2009/09.

Teunisse, J.P. (2009). Weerbaar bij veranderingen; naar een levensloopbenadering voor mensen met een autistisch spectrum stoornis. Nijmegen: Hogeschool van Arnhem en Nijmegen.

Dit artikel is gebaseerd op een onderzoek gedaan door Loes Smits en Rob Mallens, 4e jaars studenten aan de HBOV Nijmegen, in opdracht van het lectoraat Levensloopbegeleiding bij autisme.

* Drs. Harold Nas is docent en lid van de kenniskring lectoraat Levensloopbegeleiding bij autisme aan de HAN. 